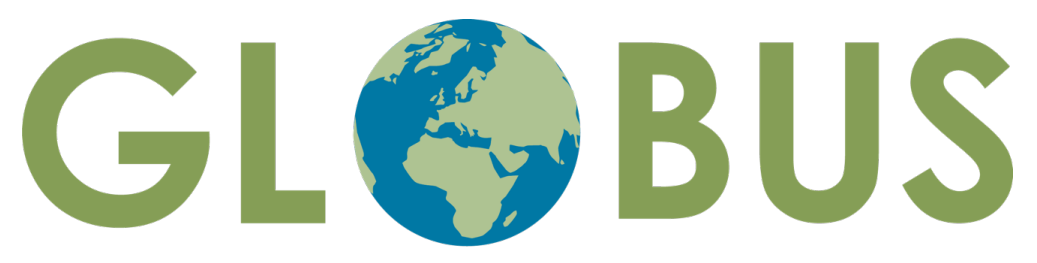

Reconsidering European Contributions to Global Justice

\title{
A Break from the Past or Business as Usual? EU-ACP Relations at a Crossroad
}

Johanne Døhlie Saltnes

GLOBUS Research Papers 10/2020 - April 2020 
Johanne Døhlie Saltnes

A Break from the Past or Business as Usual? EU-ACP Relations at a Crossroad GLOBUS Research Paper 10/2020

April 2020

(C) Johanne Døhlie Saltnes

GLOBUS Research Papers (online) | ISSN: 2535-2504

http://www.globus.uio.no/publications/globus-research-papers/

Johanne Døhlie Saltnes is Postdoctoral Fellow at ARENA Centre for European Studies, University of Oslo

Reconsidering European Contributions to Global Justice (GLOBUS) is a research project that critically examines the EU's contribution to global justice.

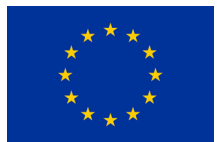

Funded by the European Union's Horizon 2020 programme. This work is the sole responsibility of the author. It does not reflect the opinion of the EU. The Research Executive Agency is not responsible for any use that may be made of the information it contains.

\section{www.globus.uio.no}

Twitter: @globus_h2020

f Facebook: @globus.h2020

Issued by:

ARENA Centre for European Studies

University of Oslo

P.O. Box 1143 Blindern

0318 Oslo, Norway

www.arena.uio.no

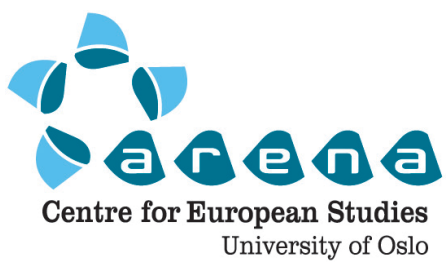




\section{Abstract}

Recent scholarly literature on the EU's development policy has argued that the Union is using its provision of development cooperation to advance its geo-strategic interests. This paper investigates whether there has been an equivalent rupture with the EU's core normative commitment, namely to conduct a human rights-based approach to development. Contrary to the hypothesis of change, I find that continuity characterises the EU's mandate for a new partnership with the Africa, Caribbean and Pacific group of states. In fact, the EU's commitment to a rights-based approach to development shaped the EU's negotiating directives for a post-Cotonou agreement. In particular, the EU sought to make sure that human rights commitments in the self-standing EPA trade agreements were not lost, as these relied on references to the Cotonou-acquis. However, drawing on a concept of justice as impartiality, I also find that there are ambiguities to the EU's rights-based approach. I find that national executives' delegated authority to initiate and conduct dispute settlement on violations of the Cotonou-acquis comes at the cost of promoting individuals' and civil society's right to autonomy. Arguably, the EU's political conditionality policy prioritises support to dutybearers (states) to uphold their obligations over the empowerment of rights-holders (individuals) to claim their rights.

\section{Keywords}

EU development policy, human rights, impartiality, justice, post-Cotonou, rightsbased approach to development

Research for this paper has received funding from the European Union's Horizon 2020 research and innovation programme under grant agreement no. 693609 (GLOBUS). 


\section{Introduction}

The EU's development policy is at a crossroad. A new agreement with the EU's historically most important development partners, the African, Caribbean and Pacific group of states (ACP) is currently being negotiated, the so called post-Cotonou negotiations. Further, Brexit and the EU's long-term budget may cause alterations to the EU's development policy as we currently know it. In addition to this apparent critical juncture, the EU finds itself in a different international context than a decade ago. International politics has taken a turn with the election of leaders like Donald Trump and Jair Bolsonaro. The new Commission has voiced an ambition to be geopolitical and the turn to interest-based and protectionist world politics is visible inter alia in the Global Strategy's goal of being guided by 'a realistic assessment of the current strategic environment' (EEAS, 2016: 8). Within this new international context, the EU has decided that: 'Development policy also needs to become more flexible and aligned with our strategic priorities' (EEAS, 2016: 11).

This latter statement stands in contrast to how the EU has defined its development policy since the beginning of EU integration. In the first memorandum on development cooperation, the Commission states that it seeks through its development policy to 'contributing to the creation of a more just international order' which results in 'better conditions of life and of fulfilment of mankind (Commission of the European Communities, 1972). Further, during the 'new season' in the late 1990s and early 2000 s aid effectiveness principles such as ownership, alignment and transparency were consolidated as the main guiding principles for how the EU would operate in relation to developing countries (Bergmann et al., 2019: 401; Carbone, 2011). In addition, the EU commits to conduct a rights-based approach to development (Council of Ministers, 2014).

Recent EU statements, indicating a turn to geo-politics and using EU development policy to advance the Union's interests abroad, may indicate a rupture with the past. These statements have not gone unnoticed. Scholars have hypothesised a change in the EU's development policy, most commonly labelled an instrumentalisation or securitisation of EU development assistance (Castillejo, 2017; Hadfield, 2007; Hadfield \& Lightfoot, 2020; Keukeleire \& Raube, 2013; Orbie \& Delputte, 2019). ${ }^{1}$ While most scholars considers this a new trend, Bergmann et al. (2019) sees it as a 'return to form', namely a return to the EU's initial approach to development pre-Maastricht. This literature highlights that the EU's development funds are increasingly being used to serve the security purposes and halting migration to the EU. Hence, the allocation of funds is determined by self-interested rather than pro-growth considerations. Looking at debates over the proposed new instrument for external action, Hadfield and Lightfoot (2020) conclude that 'The forces for development appear to be losing the battle for the normative direction of the EU's external policy to those who wish to see development supporting the strategic goals of the Union'. In a similar vein, civil society

${ }^{1}$ See also: Carbone (2013a, 2013b), Furness \& Gänzle (2017), Langan (2018b), Lavenex \& Kunz (2008) and Youngs (2008). 
has criticised the EU for using aid-funds to tackle other priorities such as migration management and containing terrorism, visible in the EU trust fund for Africa (CONCORD, 2018a, 2018b; Parkes, 2017). These various critiques of the EU development policy seem to have in common that they challenge the fairness of distributive changes in the EU's development policy. The EU's funds are seen to be diverted to purposes other than pro-poor sustainable development. In essence, this critique speaks to the question of a just distribution of EU development funds.

Notwithstanding this critique, it is necessary to make a closer inspection of the hypothesis that the EU's development policy is changing. The EU, together with its member states, accounts for the world's largest development assistance budget, illustrating the importance of the EU's distributive choices. Nevertheless, analyses of the Union as a global actor have rather highlighted its ambition to promote and export values and norms such as human rights, democratic principles and the rule of law as well as its ambition to integrate human rights in the process of development. Some scholars hold that this commitment to respect and promote values and principles makes the EU a distinct foreign policy actor (Aggestam, 2008; Manners, 2002; Rosecrance, 1998; Whitman, 1998). One of the ways the EU has pursued this ambition in its relation to developing countries is to include a human rights clause in its cooperation agreements (Saltnes, 2018). Through this clause, the parties to the agreement are entitled to suspend the agreement, including development cooperation funds, in full or in part should the other party fail to fulfil its obligations with respect to global values. Hence, in order to determine whether the EU's development policy is changing, it is necessary to also look into whether there is a change also in the normative grounding of EU development policy. Do the EU's recent policy choices suggest that the Union is moving away from, or weakening, its commitment to a rights-based approach to development? While a change in the fundamental principles on which development policy rests seems unlikely, since these principles are enshrined in the EU's treaties, it might be that these normative foundations are given less attention or prominence in the EU's current development initiatives. For instance, one could envisage a weakening of human rights conditionality in international cooperation agreements.

Then, in this working paper, I contribute to a closer inspection of the hypothesis that the EU's development policy is changing. Distributive changes set aside, I ask: What characterises the EU's rights-based approach to development and has this approach changed in the EU's proposal for EU-ACP relations beyond 2020? Why or why not? I engage with these questions through a case-study of the EU's proposed partnership with the African, Caribbean and Pacific group of states, the so called post-Cotonou Agreement.

The paper proceeds in the following way. The first section discusses how the EU's development policy has been analysed to date and sets out how I will use a global justice perspective to provide a novel and critical analysis of the EU's rights-based approach to development. I further discuss my methodological approach and how I have operationalised the key concepts in the analysis. In the subsequent section I analyse the EU's commitment to a rights-based approach and consider whether the process, 
leading to the EU's mandate for the post-Cotonou negotiations, represents a break with the past. Ultimately, I discuss limits and ambiguities to the EU's rights-based approach from a global justice perspective.

\section{Analytical framework}

In the realm of development, the EU has presented itself as an actor that seeks to contribute to a more just international order by promoting sustainable development through a rights-based approach (RBA):

The Council underlines that respect for and protection and fulfilment of human rights is a prerequisite for achieving sustainable development. A rights-based approach to development cooperation can significantly contribute to the realisation of human rights. This approach is premised on human rights principles and standards being both a means for and goal of effective development cooperation.

(Council of Ministers, 2014)

The EU's commitment to a rights-based approach has also been highlighted by scholars (Broberg, 2013; D'Hollander et al., 2014). Some see this as a distinctive trait of the EU: 'Something akin to a "European" vision and approach has been emerging. Even within the so called "western" donor landscape, the EU has increasingly differentiated itself" (Orbie et al., 2017: 505). These scholars stress that the EU development norms are politically oriented, meaning that they go beyond an economic view of growth and poverty reduction and emphasises rights, equality and social justice as 'intrinsic aims' of its development policy (ibid.).

However, the EU's commitment to a rights-based approach has also been met with scepticism. Critiques of the Union's approach has come mainly from two camps. First, scholars that relies on rationalist approaches to international relations have pointed to the fact that the EU is inconsistent in its approach. In particular, these scholars argue that the EU's human rights commitments are mere rhetoric and that the Union only takes this commitment seriously in relation to countries that are of little economic or strategic interest to the Union's member states (Crawford, 2001; Crawford \& Kacarska, 2019; Olsen, 2002; Smith, 1998, 2014; Taylor, 2016). Second, relying on postcolonial perspectives, another group of scholars is less concerned with the EU's intention but rather argue that asymmetrical power-relations between Europe and Africa enables the EU to promote Eurocentric knowledge and behaviour and overlooking local ones (Langan, 2018a; Rutazibwa, 2010; Staeger, 2016). In essence, these literatures question the fairness, usefulness and effectiveness of the EU's rights-based development policy.

While these scholars implicitly touch upon the question of whether the EU's approach can be considered fair, their analyses remain oriented around the question of what stands in the way of justice. These literatures seldom consider the question of what would be needed for the EU's policies to be considered just or fair. Their focus on the 
unfair characteristics of the EU's policies follow from their choice of theory. Interestbased accounts understand the EU's choices as a result of a calculation of instrumental costs and benefits. Postcolonial scholars on the other hand rely on the assumption that power asymmetries between the West and developing countries enable Western elites to impose their conception of a good life on other countries. Regardless of their good intentions (or not), this Eurocentrism leads to a marginalisation of non-European perspectives on what constitutes a good life. These theoretical assumptions enable these scholars to draw important insights into the shortcomings of the EU's approach. Nevertheless, these perspectives do not contain the theoretical tools necessary to consider in what way such injustices could be mitigated, or indeed, what would constitute a just and fair approach. Then, to complement these literatures, I will in this paper engage with global justice theories to answer the question of what characterises the EU's rights-based approach to development and identify ambiguities to the EU's approach. In doing so, I take the literature on the EU's development policy a step further by analysing the EU's approach from novel and critical angle.

\section{A global justice perspective on rights-based approaches to development}

Today, most developed countries conduct some form of 'development policy' towards developing countries. Such development policies normally entail (but are not limited to) the distribution of funds to states that are less well off. The context is global, as development policies affect citizens that reside outside the state that is conducting the policy. At first sight then, development policies speak to the question of what is a fair distribution of goods and resources globally.

However, the ambition to conduct a rights-based approach to development reflects the view that development policy is not only about the fair distribution of goods. Basic human rights are a core concern also in policies that reaches across borders. Rightsbased approaches highlight that human rights are important not only in substance, but also in the procedures through which development policy is carried out. A rights-based system of rule is considered equally important to rights-based policies. This attempt to create a fair system of rule and procedures through which development policy is carried out can be viewed as an ambition to reduce and mitigate the arbitrary use of power. For instance, through human rights conditionality, a cornerstone of the EU's development policy, the contracting parties are bound to respect human rights, democracy and the rule of law in their policies, and the parties have agreed on a set of procedures through which the violations of these elements should be followed. Accordingly, these actors are bound by specific procedures, and the space for taking advantage of power asymmetries are reduced. In other words, actors are bound by rules and not by their power.

The attempt to strengthen a rules-based order and reduce the space for taking advantage of power asymmetries could be interpreted in line with a concern for reducing domination. Mitigating the arbitrary wielding of power, the basic definition 
of domination, is a core concern in both 'republican' and 'cosmopolitan'2 conceptions of justice. However, these theories of justice vary with regard to how they propose to mitigate domination. In essence, justice is a contested concept, and the strategies and policies that different variants of justice theory prescribe prioritise different solutions. Put simply, cosmopolitan variants focus on mitigating domination of individuals while republican variants focus on achieving non-domination between states.

The core of RBAs is the aim to support duty-bearers to fulfil their human rights obligations and rights holders to claim their rights (Uvin, 2004, 2007). In emphasising a set of internationally agreed set of legal human rights norms, a rights-based approach to development is distinctive in that it provides a stronger basis for citizens to make claims on their states and for holding states to account for their duties to enhance the access for their citizens to the realisation of their rights' (Cornwall \& Nyamu-Musembi, 2004). These core propositions of RBAs resonate with the solutions prescribed by cosmopolitan variants of justice theory. Cosmopolitanism considers individual human beings to be the rightful unit of moral concern and claimant to justice. To secure individuals' freedom and autonomy, cosmopolitans argue for an international system that sets individual human rights at its core (See for instance Mikalsen, 2017 for an overview). While sovereign states are important elements of today's international order, the EU has for instance been denoted as a cosmopolitan vanguard (Beck, 2006; cf. Eriksen, 2009).

In the following I propose to use the GLOBUS concept of justice as impartiality (Eriksen, 2016; Sjursen, 2017) to analyse the EU's ambition to conduct a rights-based development policy and to assess whether there has been a change in the EU's approach. 3 The added value of using the concept of justice as impartiality to study the EU's rights-based approach is that it provides a normative benchmark for what a just and fair rights-based approach could look like. Against this normative benchmark, it is possible to make an assessment of how the EU fares. Furthermore, the concept of justice as impartiality comes with certain explicit strengths and weaknesses (see below). These traits enable us to critically discuss the EU's rights-based development policy in light of the contestation and critique that the EU has met from its partners in the ACP countries.

In line with cosmopolitan variants, the ultimate concern according to a conception of justice as impartiality is to secure individuals' autonomy. To be free, an individual must be enabled to co-determine the laws she is subjected to. Strong institutions, both at the domestic and at the global level, are necessary to secure equal protection of individuals' human rights (Forst, 2015). Such powerful and impartial institutions can serve as arbitrators who operate on a "neutral standard for dealing with colliding values and norms' (Eriksen, 2016: 14). It is imperative that 'the rights secured by justice are not subject to political bargaining or to the calculus of social interests' (Rawls, 1971: 4

${ }^{2}$ See Mikalsen (2017) for an overview of the main propositions in these theories.

3 GLOBUS - Reconsidering European Contributions to Global Justice is a H2O2O-funded research project that critically examines the EU's contribution to global justice. See: www.globus.uio.no 
quoted in Eriksen, 2016: 3). Impartial institutions and principles thereby serve to enable individuals to challenge those who might subject her to domination, viz. give individuals the power to challenge their leaders and peers when violations occur.

A conception of justice as impartiality requires stronger institutions than many of those that govern international relations today. Under international law, states are the principal agents that bear the duty of ensuring human rights for their citizens. However, from the viewpoint of impartiality, states are not enough. We need international binding laws and principles that can hold states to account. The need for holding states to account for their rights-commitments is also one of the defining elements of rights-based approaches. Groups and individuals as well as the international community are viewed as being entitled to hold states accountable by referring to internationally agreed norms and rules. Understanding RBA through a lens of justice as impartiality emphasises the viewpoint that rights enhance 'the ability of individuals to influence those decisions that affect them' (Sjursen, 2017).

Justice as impartiality provides a strong basis for individuals to engage in the protection and realisation of their rights by appealing to global norms and principles for appropriate action. For instance, oppressed citizens can make use of networks and actors outside their own state to fight for their rights. They can advocate for international actors to exert pressure on their oppressors, which might include their own state, transnational companies or international organisations. One illustrative example is how LGBTI human rights activists have managed to influence powerful donors such as the United States to exert pressure on their own governments when adopting anti-gay laws (Saltnes, 2020).

However, the concern for strengthening individuals' ability to realise their rights might also face criticism. Although human rights are principles that 'no one can reasonably reject' (Eriksen, 2016: 17), a conception of justice as impartiality may be contested from several angles. On democratic grounds one could raise the objection that the intervenors are not democratically elected by the citizens whose human rights have been violated. Thereby, these citizens and their states are deprived of their right to exercise sovereignty. For neo-colonial scholars, what is more problematic is that universal human rights principles can be used to justify measures to protect individuals from harm, without these individuals being consulted. As a result, these measures might be against their will and result in charges of paternalistic intervention (Staeger, 2016). Nussbaum, in her defence of universal values, describes charges of paternalism as follows:

When we use a set of universal norms as benchmarks for the world's varied societies, telling people what is good for them, we show too little respect for people's freedom as agents [...] People are the best judges of what is good for them, and if we prevent people from acting on their own choices, we treat them as children.

(Nussbaum, 1999: 16) 
Hence a development policy based on a concept of justice as impartiality will run the risk of being contested on democratic grounds and face charges of paternalism. Such charges are often accompanied by a plea for less intervention and respect for states sovereignty (Langan, 2018b; Rutazibwa, 2010; Staeger, 2016). In the analysis below I will draw on these critiques of a concept of justice as impartiality to discuss limits and ambiguities of the EU's rights-based policy. Before I embark on the analysis, I will in the next two sections describe the operationalisation and methodology that I make use of in the analysis.

\section{Methodology and operationalisation}

To answer the questions of what characterises the EU's rights-based approach to development and whether the EU's proposition for a new partnership with the ACP states represents a break with the past, I conduct a case study of the EU's negotiating directives to the post-Cotonou negotiations. I use the Cotonou-acquis as the benchmark for the EU's policies and empirically analyse whether there has been a strengthening or weakening on obligation, precision and delegation of the EU's approach in the postCotonou mandate. The method applied is a qualitative analysis of the EU's approach, combining document analysis and an analysis of justifications for the EU's approach provided in semi-structured interviews with EU policymakers.

The case of post-Cotonou was chosen due to its centrality in the process of defining EU development policy post-2020 and represents what Gerring (2007) labels an influential case. The EU is currently at a crossroad where several parallel processes determining the future of the Union's approach to development. The new European Consensus on development has already given some indications for the EU's future approach. The exit of a policy leader and key financial contributor to the EU's development policy through Brexit (Price, 2019), the Commission's proposal for a major overhaul of the mechanisms financing external action (Hadfield \& Lightfoot, 2020) and the postCotonou negotiations will further define the direction of the Union's development approach post 2020. Furthermore, if a new agreement is concluded, post-Cotonou will cover EU relations with 79 countries and thereby cover a significant part of the EU's relations with developing countries. In the context of the literature on EU development policy, which hypothesises a rupture with the past and a change towards a more interest-driven approach, post-Cotonou is an influential case because it may represent a deviation from status quo. However, the extent to which a shift has taken place is open to empirical investigation.

To operationalise the concept of justice as impartiality and further investigate whether there has been a change in the EU's commitment to a rights-based approach, I choose to focus on the extent to which the EU has strengthened international binding human rights laws and principles that can enable individuals to hold their rulers to account. To do so, I draw on the concept of legalisation (Abbott et al., 2000). Legalisation can be seen as an expression of the extent to which 'institutions have obligatory and precise 
rules that can be interpreted by neutral arbiters' (Van den Putte et al., 2013). In view of the concept of justice as impartiality, the element of delegation is particularly useful. Justice as impartiality holds that the institutionalisation of human rights enhances individuals' autonomy by raising their ability to influence decisions that affect them. The question of who has access to request arbitration as well as who has access to the arbitration as such is imperative. This might vary from delegated officials of states to be open to individuals (see below). Arguably, the concept of legalisation provides the tools necessary to investigate whether the EU's approach resembles 'a neutral arbitrator' that 'prevent dominance among states' as well as whether there has been a weakening of the EU's approach in recent proposals (Eriksen, 2016: 13).

The concept of legalisation refers to 'a particular set of characteristics that institutions may or may not possess' (Abbott et al., 2000: 401). These characteristics are: obligation, which determines the extent to which the rule is legally binding, precision which, refers to the extent to which rules define appropriate conduct and delegation, which defines who and how actors implement, interpret and apply the rule. Table 1 below summarises the operationalisation of the concept. Obligation can vary from legally binding agreements (high) to recommendations and guidelines (low). Precision refers to whether a rule 'clearly and unambiguously' specifies what behaviour is expected from the parties (Abbott et al., 2000: 412). It can vary from determinate rules which imply only narrow issues of interpretation to standards and principles that are contingent on specific situations and leaves a wide room for interpretation by delegate authority. Ultimately, delegation refers to the extent to which there is delegated authority to third parties to implement, interpret and solve disputes. A high level of delegation could include neutral third-party arbitrators such as courts. We would expect binding arbitration such as dispute settlement mechanisms, while a low level of delegation would be indicated by diplomatic activities such as political dialogue between the parties. It is on the dimension of delegation that a possible change in the EU's RBA is expected to be most plausible.

In addition to the relative neutrality of the actors that are delegated the authority to settle disputes, I highlight access to arbitration, namely which actors are entitled to require an initiation of dispute settlement (Keohane et al., 2000). Delegation is high if a broad set of actors are entitled to require arbitration, while a low degree would be indicated by only executive authorities being able to initiate such mechanisms. Altogether, the qualitative interpretation of obligation, precision and delegation will indicate whether the EU's rights-based approach is high or low on legislation. High legalisation would indicate practices that are approximate to a conception of justice as impartiality, while low legalisation would indicate limits and ambiguities with regards to this particular justice standard. 
Table 1: Operationalisation

\begin{tabular}{|llll|}
\hline High & $\begin{array}{l}\text { Obligation } \\
\text { Legally binding }\end{array}$ & $\begin{array}{l}\text { Precision } \\
\text { Precise and narrow }\end{array}$ & $\begin{array}{l}\text { Delegation } \\
\text { Courts, dispute settlement } \\
\text { mechanisms }\end{array}$ \\
\hline Indicator & $\begin{array}{l}\text { Human rights } \\
\text { clauses in legally } \\
\text { binding agreements }\end{array}$ & $\begin{array}{l}\text { Definition of what } \\
\text { constitutes breaches } \\
\text { of the agreed } \\
\text { principles }\end{array}$ & $\begin{array}{l}\text { Independent actors operate within a } \\
\text { set system of arbitration } \\
\text { Broad set of actors can require } \\
\text { dispute settlement }\end{array}$ \\
\hline Low & $\begin{array}{l}\text { Recommendations } \\
\text { and guidelines }\end{array}$ & $\begin{array}{l}\text { Contingent on } \\
\text { specific situations }\end{array}$ & Diplomacy \\
\hline Indicator & $\begin{array}{l}\text { Voluntary } \\
\text { commitment to } \\
\text { human rights } \\
\text { standards }\end{array}$ & $\begin{array}{l}\text { No interpretation or } \\
\text { definition provided }\end{array}$ & $\begin{array}{l}\text { Political dialogue between disputing } \\
\text { parties reserved for executive } \\
\text { authorities } \\
\text { Only executive authorities can }\end{array}$ \\
& & & $\begin{array}{l}\text { Onuire dispute settlement } \\
\text { requing }\end{array}$ \\
\hline
\end{tabular}

The analysis is conducted on the basis of official documents from the EU as well as semi-structured interviews with EU policymakers involved in the drafting and negotiation of the EU's negotiating directive (see list at the end of the paper). Interviewees were selected on the criteria of being central to the process of formulating the mandate (representatives from the Commission and the EEAS) and from the European Parliament, which with its report (European Parliament 2016) sought to influence the negotiation directive. In addition to the interviews, I have analysed all the central official documents on post-Cotonou. Table 2 below lists the official documents that have been analysed. In accordance with Bergmann et al. (2019), I consider the EU's official documents to serve as 'key signposts' for determining the direction and possible changes in EU development policy. The process of consolidating the negotiation directives for post-Cotonou materialised in three politically approved official documents. The Commission and High-Representative (HR) first published a joint communication in November 2016. In December 2017, a recommendation from the Commission and HR to the Council followed. Then after a process of negotiations between the member states, the Council adopted its mandate in June 2018. Prior to this a public consultation procedure was carried out (Commission and EEAS 2016) as well as an impact assessment of the Cotonou Agreement (Commission and HR 2016b). These two latter documents are working documents of the Commission and the EEAS and thereby not politically approved by the Council, however, they give insights into the early stages of the process of consolidating the EU's approach towards Cotonou and are therefore equally relevant to analyse. The European Parliament delivered its report on the future of ACP-EU relation in September 2016. 
Table 2: Analysed official documents on Post-Cotonou

\begin{tabular}{|c|c|c|}
\hline Institution & Year & Document \\
\hline $\begin{array}{l}\text { Commission } \\
\text { and HR }\end{array}$ & 2016 & $\begin{array}{l}\text { Joint Communication to the European Parliament and the Council. A } \\
\text { renewed partnership with the countries of Africa, the Caribbean and } \\
\text { the Pacific }\end{array}$ \\
\hline $\begin{array}{l}\text { Commission } \\
\text { and HR }\end{array}$ & 2016 & $\begin{array}{l}\text { IMPACT ASSESSMENT Accompanying the document Joint } \\
\text { Communication to the European Parliament and the Council: A } \\
\text { renewed partnership with the countries of Africa, the Caribbean and } \\
\text { the Pacific. }\end{array}$ \\
\hline $\begin{array}{l}\text { European } \\
\text { Parliament }\end{array}$ & 2016 & $\begin{array}{l}\text { Report on the future of ACP-EU relations beyond 2020, committee on } \\
\text { development. }\end{array}$ \\
\hline $\begin{array}{l}\text { Commission } \\
\text { and HR }\end{array}$ & 2017 & $\begin{array}{l}\text { Recommendation for a Council Decision authorising the opening of } \\
\text { negotiations on a Partnership Agreement between the European } \\
\text { Union and countries of the African, Caribbean and Pacific Group of } \\
\text { States }\end{array}$ \\
\hline Council & 2018 & $\begin{array}{l}\text { Negotiating directives for a partnership agreement between the } \\
\text { European Union and its member states on the one part, and with } \\
\text { countries of the African, Caribbean and Pacific group of states, of the } \\
\text { other part. }\end{array}$ \\
\hline
\end{tabular}

\section{Analysis: Change or continuity in the EU's development policy?}

Then, what characterises the EU's rights-based approach to development and has this approach changed in the EU's approach to post-Cotonou? Why, or why not? To answer these questions, I first analyse the EU's commitment to a rights-based approach and in particular how this approach materialised in the Cotonou-agreement. Subsequently, I analyse the process leading to the EU's negotiating directives on post-Cotonou and consider whether this represents a break with Cotonou and why the EU chose this approach. Ultimately, I discuss limits and ambiguities of the EU's rights-based policy in the Cotonou agreement and the post-Cotonou negotiating directives in light of a conception of justice as impartiality.

\section{The EU's rights-based approach: Conditionality and the Cotonou-acquis}

The EU has, since the very start of EU integration, prioritised its member states former colonies and protectorates as the main recipients of EU development policy. In 1964 the EU initialled a set of international agreements with the ACP states regulating a comprehensive set of trade and aid activities: the Yaoundé Conventions (1964-1975), the Lomé Conventions (1975-2000) and the Cotonou Partnership Agreement (20002020) (CPA). Through these agreements, the EU has promoted respect for human rights as part of its foreign policy and development policy. It was not until the Maastricht treaty that an explicit commitment to promote democratic principles and 
human rights through its external policies were legally introduced. The Maastricht treaty's Article 13ou linked EU development policy to the human rights, democracy, fundamental freedoms and the rule of law (European Union, 1992). In the aftermath of Maastricht, human rights principles have been strengthened. With the adoption of the Lisbon treaty, the EU's Charter of Rights was given legal status. The EU's commitment to human rights in its foreign policy is enshrined in Article 21(1) of the Treaty on European Union:

The Union's action on the international scene shall be guided by the principles which have inspired its own creation, development and enlargement, and which it seeks to advance in the wider world: democracy, the rule of law, the universality and indivisibility of human rights and fundamental freedoms, respect for human dignity, the principles of equality and solidarity, and respect for the principles of the United Nations Charter and international law.

(European Union, 2007)

Article TFEU 208 further states that the Union shall conduct its development policy 'within the framework of the principles and objectives of the Union's external action'. With the adoption of the Lisbon treaty, the EU 'has come under an indispensable duty to further European values such as human rights, democracy and the rule of law' (Broberg, 2013: 683).

In recent years, the EU has released several documents that elaborates on the Union's approach to promoting human rights as part of their external action. Central documents are the EU strategic framework and action plan on human rights and democracy (Council of Ministers, 2012); Human rights and democracy at the heart of EU external action - Towards a more effective approach (European Commission \& High Representative, 2011); Council conclusion on a rights-based approach to development cooperation, encompassing all human rights (Council of Ministers, 2014); and a Commission tool-box: Rights-based approach, encompassing all human rights for EU development cooperation (European Commission, 2014). The EU has provided the following definition of its commitment to RBA:

The intrinsic rationale behind the HRBA is to move development cooperation beyond voluntary cooperation and into the mandatory realm of law. In framing development in terms of human rights, an HRBA re-conceptualises traditional development, re-orients the objectives of development cooperation towards international human rights treaty standards, and redefines the role of 'stakeholders into groups or individuals who have human rights or rights to claim (rights holders) and those who have duties to respond (duty bearers).

(European Commission, 2014: 6)

Whereas these documents defining the EU's rights-based approach are recent, the definition does not deviate from earlier documents but rather specifies how respect for human rights serves as a cornerstone of the EU's policy. 
A central feature of the EU's RBA is the conditioning of cooperation agreements on respect for human rights, democratic principles and the rule of law (often referred to as political conditionality). The decision to make human rights principles conditional for the EU's development policy was first made in 1991 (EPC Bulletin, 1991). The EU decided to insert human rights clauses into all of the Union's future trade and development agreements. If one party to the agreement were to be involved in human rights violations, the other party would be entitled to suspend the agreement in whole or in part.

What is often referred to as the Cotonou-acquis by policymakers as well as scholars of EU development policy is the most comprehensive materialisation of a human rights clause in an EU cooperation agreement to date (Beke et al., 2014). The Cotonou Partnership Agreement's main objectives were to reduce and eventually eradicate poverty and the gradual integration of ACP countries into the world economy (Article 1 CPA). While a human rights clause was already introduced in its predecessor Lomé IV, human rights conditionality was strengthened in the CPA. Cotonou includes an article defining the partnership's essential elements (Article 9) and a non-execution clause (Article 96). ${ }^{4}$ Article 96 sets out the procedures for how the parties to the agreement will operate when one party considers that the other party has not fulfilled the conditions of the agreement. Although there are different legal interpretations of such human rights clauses, there is agreement on the fact that the legal effect is that 'they contain obligations binding on the parties' (Bartels, 2015: 1079).

In view of the operationalisation set out in Table 1 above, the Cotonou-acquis has high obligation: It is legally binding for all parties to the agreement. Its precision, however, is low. Whereas article 9 clearly specifies what are considered essential elements (human rights, democratic principles and the rule of law) and a fundamental element (good governance), the interpretation of what constitutes a non-fulfilment of these obligations is not specified. As regards delegation, article 96 clearly sets out the consultation procedure for arbitration should one of the parties 'consider that the other party fails to fulfil an obligation'. If the consultation does not lead to an acceptable solution, or in cases of 'special urgency', the parties are entitled to adopt 'appropriate measures' proportional to the violation. Typically, appropriate measures could be to withhold financial funds. CPA article 96 states that it is only if all avenues for arbitration through political dialogue is exploited that the parties to the agreement can resort to sanctions or suspensions of aid (except in cases of 'special urgency') (Beke et al., 2014: 62). However, only 'the parties' are envisaged as arbitrators. Article 96(1) specifies that 'the term "Party" refers to the Community and the Member States of the European Union, of the one part, and each ACP state, of the other part'. Accordingly, initiation of the procedure as well as determining who should be the participants in the

4 For overviews of EU development policy pre-Cotonou see for instance: Holland \& Doidge (2012) and Pallotti (2018). 
consultation meetings is a decision reserved for EU and ACP executives and diplomats. In line with Abbot et al. (2000), delegation is thereby low on the indicator legalisation.

The Cotonou-acquis follows a legal reasoning. The essence of the Cotonou-acquis is to make explicit that respect for a number of principles, labelled essential elements, are premised on the reciprocal obligation of the parties, 'so that human rights violations of a certain scale by one of them could amount to a material breach of the treaty and justify suspension or other counter-measures' (Beke et al., 2014: 60). This practice resonates with the viewpoint that there is a need for a law-based order beyond the state, and that human rights protection is given priority over state sovereignty, in line with a conception of justice as impartiality. Then, to what extent has the EU's conditionality policy been weakened (or perhaps strengthened) in the proposal for post-Cotonou relations with the ACP? And, why did the EU choose this approach?

\section{Post-Cotonou: A weakening of human rights commitments?}

The current Cotonou agreement is set to expire in 2020, and the EU and ACP commenced negotiations for a successor in 2018. In the period between 2016 and 2018, the Commission and the European External Action Service (EEAS) conducted preparatory work for what finally became the Council's negotiating directives (hereinafter: the mandate). The ACP working party in the Council supervised the process and conducted the last round of negotiations before Coreper approved and published the mandate on 21 June 2018 (Interviews - 7, 8).

\section{The role of essential elements: Obligation}

With regards to obligation, the issue of including a human rights clause in postCotonou became of central importance when negotiating the mandate. In particular, this became a salient issue owing to the unresolved link between the self-standing Economic Partnership Agreements (EPAs) and the new post-Cotonou agreements. The EPAs are stand-alone trade agreements that the EU is concluding with the six ACP regions (The Pacific, the Caribbean and four African regions). Although the negotiations of these EPAs started back in 2003, only two regional agreements are concluded and ratified. The remaining agreements are either under negotiation or awaiting ratification (European Commission, 2020; Youngs, 2010) Although legal scholars argue that the EPAs would not be affected, at least in legal terms, by the expiry of the Cotonou Agreement (Keijzer \& Bartels, 2017), policymakers worried that the Cotonouacquis would be lost (Interviews - 7, 8). Several of these EPAs do not include standalone human rights clauses but rather refer to the human rights commitments in the $\mathrm{CPA}$ - the status of these commitments would be unclear were the Cotonou Agreement to expire without a successor. ${ }^{5}$ Hence the Commission and the EEAS was concerned

\footnotetext{
5 According to Carbone (2019), all EPAs make reference to the Cotonou-agreement. However, the specific commitments on human rights vary from implicit, ambiguous to explicit commitments a la those in the Cotonou agreement.
} 
with designing the post-Cotonou agreement in a way that would confirm that human rights obligations remained in the EPAs (See Carbone 2019 for a similar argument).

The EU foresees three options to a new agreement: a revised partnership with all countries; regionalisation through three separate partnership agreements; or a so called umbrella-agreement. The latter consists of two elements: a joint agreement, 'the umbrella' defining common values, principles and interests and three regional partnership agreements governing the actions focussed on the specific region (European Commission \& High Representative, 2016b). In its recommendation for a post-Cotonou mandate, the Commission recommends the Umbrella-agreement option, among other things owing to the advantage of preserving the common commitment to human rights, good governance and the rule of law:

The umbrella partnership would avoid the cost of refusing any partnership with the partner countries as a group and could preserve the Cotonou acquis, notably when it comes to essential elements and the link with Economic Partnership Agreements.

(European Commission \& High Representative, 2016b: 26)

During the EPA negotiations, DG trade negotiators were 'not very eager to include provisions on human rights as key conditions to sign the agreements' (Carbone, 2019). ${ }^{6}$ Due to the autonomous role of DG Trade, the different EPA agreements do not contain a coherent set of human rights commitments, but they all make reference to respecting the essential elements of Cotonou. The importance of locking in the human rights commitments in the EPAs was confirmed by the interviewees: 'it was already a difficult exercise to negotiate these agreements [the EPAs] [...] and they all refer to Cotonou, so it is very important that in the new agreement a link is properly made' (Interview - 7). However, as a human rights clause would be important to include no matter what, the locking in of human rights commitments in the EPAs was by some seen more as a technical issue: 'it is a question of whether it is legally waterproof' (Interview - 8). Far from being considered a technical issue, the linkage with the EPAs was central to the European Parliament's argumentation (Interviews $-5,6$ ). In its resolution the European Parliament:

Calls for a post-Cotonou Agreement as a political umbrella agreement under which binding minimum requirements for EPAs are set, in order to ensure continuity for EPA linkages in the existing Cotonou Agreement to sustainability provisions on good governance, respect for human rights, including among the most vulnerable people, and adequate framework for sustainable development and policy coherence.

(European Parliament, 2016: 12)

${ }^{6}$ See also Bilal \& Ramdoo (2016) 
Furthermore, the opinion of the committee on international trade, attached to the resolution, the trade committee:

Asks, in particular, for the human rights 'essential elements' clause to remain in the future agreement [...] so that the linkage clauses in the EPAs - especially the non-execution clauses - continue to function after 2020.

(European Parliament, 2016: 19)

From the EP's side, the need to make sure that ta human rights clause also applied to all self-standing EPA agreements was a central reason for their support for the so called umbrella version. The umbrella option would avoid any possible confusion regarding human rights commitments by defining human rights as essential elements of the new partnership in the same way as was done in the Cotonou acquis. Hence, the importance of keeping a common commitment to human rights with all ACP states, and not risking differentiated human rights commitments in the regional EPAs contributed to the choice of opting for an umbrella-agreement. The Member of the European Parliament (MEP) in charge of drafting the EP's resolution Norbert Neuser and his team consulted with a broad variety of stakeholders and civil society organisations during the drafting of the report. However, the input of these stakeholders mainly addressed substantive and thematic priorities for post-Cotonou. Yet, what was considered most important by the EP were the principles and the question of the basic institutional structure of the new agreement (Interviews $-3,4$ ).

In addition to the particular issue of locking in human rights commitments in the EPAs, the Commission and EEAS argued for the necessity to make post-Cotonou a legally binding agreement, and in particular the human rights commitments:

One of the objectives of the proposed partnership, fully consistent with EU treaty provisions, is that of promoting human right and fundamental freedoms (as well as democracy, rule of law and good governance). Should the legally binding nature of the partnership be abandoned, these commitments would be lost - and this would be undesirable, given the changing international scene with emerging powers not necessarily sharing these values and principles.

(European Commission, 2017: 6)

The legal basis is particularly important in relation to commitments made by the parties in the area of human rights, democracy, good governance and the rule of law. These solid commitments, captured in the legally-binding nature of the agreement, would be lost, if the legal nature of the partnership would be abandoned. This would give the impression that pursuing these principles is no longer a priority for the EU in its relation with ACP countries, and in EU external policies in general. 
The importance of seeking a legally binding agreement was corroborated by the interviewees (Interviews 1, 2, 7 8):

You had already a legally binding agreement with Cotonou, for 20 years, which is a very strong document and strong partnership agreement [...] everybody agreed that the so-called Cotonou-acquis, especially on human rights and democracy, it would not be useful to give it up

(Interview - 7).

It was important to keep what we have built up with them, especially in relation to the values

$$
\text { (Interview - 8). }
$$

In sum, it was considered important for the EU to pursue a legally binding agreement, in order not to go back on what had already been a strong, legally binding CPA. A similar observation is made by Carbone who concludes that:

Preservation of the long-standing commitment to human rights and democratic principles, in fact, became one of the main reasons not only for the renewal of the EU-ACP Agreement, but also for proposing a hybrid format, with the commitment to shared values included in the general part of the agreement to avoid any reopening of discussions on issues potentially sensitive for various African countries.

(Carbone, 2019: 54)

\section{Political dialogue and dispute settlement: Precision and delegation}

\section{of human rights commitments}

So far, the analysis suggests that there was no change in the obligation of human rights commitments from the Cotonou-acquis to the post-Cotonou mandate. Rather, the concern for maintaining human rights commitments in the EPAs obligatory was a central reason for the EU's choice to opt for the so called umbrella solution. However, did the envisaged human rights clause entailed changes in its precision or delegation in the EU's approach to post-Cotonou?

In the European Commission and High Representative (2016b) first proposal, political dialogue (article 8) and non-execution (article 96) are reviewed as 'useful tools' and the Council of Ministers' (2018) mandate stipulates that the agreement will include a provision similar to the human rights clause in Cotonou. Article 96 affects the element of delegation of dispute settlement and describes the process through which the parties to the agreement would follow if one of the parties deemed the essential elements not to be upheld (See Annex 1). The post-Cotonou mandate's language on essential elements and non-execution is largely in line with Article 96, although with an 
enhanced focus on political dialogue to avoid 'appropriate measures'. What is new compared to Article 96 is the following formulation:

[I]n order to prevent situations arising in which one party consider that the other Party has failed to fulfil its commitments in relation to the essential and fundamental elements of the Agreement, structured and systematic consultations will be held on concerns raised.

(Council of Ministers, 2018: 85)

Hence, it is possible to trace a concern for strengthening political dialogue and by that avoid situations that would normally lead to Article 96 consultations. Precision is accordingly increased.

The strengthening of the political dialogue element can be interpreted as a response to repeated requests by the ACP group on their wish to reduce the use of the article 96 consultation procedure (Interviews - 7, 8). The use of Article 96 of the Cotonouagreement had been contested; In addition to the critique of inconsistent application 7 from scholars, politicians and civil society actors, the EU's faced charges of neoimperialism. Rwandan president Kagame, for instance, accused the EU of having 'human rights superiority complex' (France 24, 2019). In addition, the ACP has criticised the EU for not meeting them with mutual respect (Gomes, 2013).

EU policymakers are well aware of these critiques and were concerned with emphasising the difference between regular political dialogue on human rights issues and the article 96 consultation procedure.

In Cotonou, sometimes political dialogue was perceived as a pre-chamber to article 96 consultations, which it actually isn't [...] It is not stated in the agreement like that but it was perceived like that... we have to see how we can make this clearer, so that the partners are more open to political dialogue, which should affect all areas of our partnership, not only controversial issues.

(Interview - 7)

In their mandate for post-Cotonou, the ACP made an explicit call for strengthening political dialogue and thereby avoiding Article 96 consultations. The mandate suggests making political dialogue and advocacy one of three proposed pillars for the new agreement. The ACP mandate emphasises that one of the objectives of a strengthened political dialogue is to 'prevent situations arising in which one Party might deem it necessary to have to recourse to the consultation procedures' (ACP, 2018: 34).

The critique of the EU's approach to human rights conditionality illustrates that a policy that emphasises human rights is vulnerable to accusations of paternalism. The EU's formulation on preventing situations that will lead to consultations illustrates that

7 See Saltnes (2018) for an overview of the critique of inconsistency. 
the EU acknowledges the weaknesses of this approach and it goes some way in meeting the ACP's wishes.

As regards delegation, are some indications of a move towards more consistently including non-state actors in the partnership. The EU wants to 'build on a multistakeholder approach, going beyond governments which cannot handle the challenges alone' and make 'broad participation of state and non-state actors' a fundamental principle for cooperation (European Commission \& High Representative, 2016b: 27). Similarly, in the final mandate, the Council of Ministers (2018: 6) states:

The Agreement will state that the Parties will promote a multi-stakeholder approach, enabling the active engagement of a wide variety of actors in dialogue and cooperation processes, including parliaments, local authorities, civil society and the private sector.

(Council of Ministers, 2018: 6)

However, beyond such general statements of an ambition to include a variety of actors in the partnership, there are no indications that the central processes of arbitration between the parties, such as dialogue and dispute settlement, will be opened to participation by a broader set of actors.

Table 3: Legalisation of human rights in Cotonou and Post-Cotonou

\begin{tabular}{|llll|}
\hline Cotonou & $\begin{array}{l}\text { Obligation } \\
\text { High }\end{array}$ & $\begin{array}{l}\text { Precision } \\
\text { Medium/low }\end{array}$ & $\begin{array}{l}\text { Delegation } \\
\text { Low } \\
\text { human rights clause }\end{array}$ \\
\hline $\begin{array}{l}\text { Post- } \\
\text { Cotonou }\end{array}$ & High & $\begin{array}{l}\text { Interpretation of what } \\
\text { constitutes a non- } \\
\text { fulfilment of obligation not } \\
\text { specified }\end{array}$ & $\begin{array}{l}\text { Article 96 defines procedure for } \\
\text { dispute settlement } \\
\text { A96 reserved for executive } \\
\text { authorities to initiate }\end{array}$ \\
\hline & $\begin{array}{l}\text { Legally binding } \\
\text { human rights clause } \\
\text { envisaged, new } \\
\text { elements included }\end{array}$ & $\begin{array}{l}\text { Increased precision on } \\
\text { political dialogue as a } \\
\text { measure used to avoid } \\
\text { resorting to non-execution }\end{array}$ & $\begin{array}{l}\text { Lon-execution clause } \\
\text { envisaged, however, reserved } \\
\text { for executive authorities to } \\
\text { initiate }\end{array}$ \\
\hline
\end{tabular}

The analysis shows that the EU has opted for continuity in its approach towards the Post-Cotonou negotiations. Contrary to the hypothesis of a change in the EU's development policy, it has been established that the reason for opting for an umbrella version was the wish to secure continuity on the Cotonou acquis. The EU opts for making the entire agreement dependent on the non-violation of human rights. Moreover, the EU continues to opt for a legal approach to uphold human rights and the protection of marginalised and discriminated individuals and groups through a detailed prescription of obligation, precision and delegation of dispute settlement.

While the EU's approach can be viewed as a plea to continue a rules-based order of governance with its partners, there are also some limits to the EU's approach, which I 
now turn to. In particular, I will focus on the extent to which the EU's RBA creates a stronger basis for citizens to hold their states accountable.

\section{Discussion: Limits and ambiguities to the EU's rights- based approach}

Above, I have argued that the concern for continuing human rights conditionality was the main reason for the EU to propose an umbrella agreement to its partners in Africa, Caribbean and Pacific post 2020. Through this conditionality, the contracting parties are bound to respect human rights, democracy and the rule of law, and the parties have agreed on a set of procedures through which the violations of these elements should resolved. In addition, I have argued that the human rights conditionality can be seen as a cornerstone of the Union's ambition to conduct a rights-based development policy. Through human rights conditionality, the EU has sought to support duty-bearers to fulfil their human rights obligations as well as rights-holders to claim their rights. However, in view of the concept of justice as impartiality, there are limits and ambiguities to the EU's conditionality policy. In the following, I will focus on twointerrelated ambiguities that are visible in the EU's interpretation of a rights-based approach to development. The first concerns the EU's interpretation of dispute settlement as a process between national executives in the EU and ACP countries only. In a similar vein, a second ambiguity of the EU's approach concerns the choice to restrict delegated authority to initiate or request dispute settlement to national and EU executives only. Relying on executive institutions presents a challenge to individuals' autonomy to claim and realise their rights.

A central proposition derived from the concept of justice as impartiality is to secure the individual's autonomy. To be free, the individual must be a co-determining agent in the laws she is subjected to (Forst, 2015). A first requirement would be that the individual is 'author of the laws that she has to obey' (Sjursen, 2017: 8). At the international level, this could materialise in legal binding norms codified in international declarations, treaties and convenants. Hence, the co-determining agents are 'states with particular conceptions of basic rights as well as persons who make particular claims, possibly dissenting from their states' conceptions' (Forst, 2018: 207). Furthermore, to secure individual autonomy, co-determining agents must have access to justification authority' as a 'justificatory equal'. In the context of international human rights legislation, 'a reflection on which rights violations ought to lead to which sanctions and by which prior procedure and through which agent needs to be included (Ibid.). Accordingly, a structure of justification is needed for individuals to be able to challenge those who might subject her or him to domination. In other words, states must be bound by supranational rules which gives individuals the power to challenge their leaders when violations occur.

In the above analysis, I made use of the concept of legalisation to determine whether there had been changes to the EU's rights-based approach to development. While I 
found that the EU had opted for continuity rather than change, the element of delegation may prove particularly relevant if we want to assess the EU's approach from a justice as impartiality viewpoint. Delegation concerns who are entitled to implement, interpret and apply the rules that are agreed upon and how they do it. Hence, it also lays out the procedures through which individuals are enabled to hold their states to account. In the following, two points will be discussed with reference to the EU's approach: who is given delegated authority to participate in dispute settlement and who is given delegate authority to initiate dispute settlement.

As we have seen, the Cotonou-acquis spells out procedures for how disputes on human rights, democracy and the rule of law should be handled. The Cotonou-agreement's article 96 sets out procedures for dispute settlement on human rights violations. In this Article the EU conceives of dispute settlement mainly as an authority to authority process carried out by 'the parties' to the agreement. Conflict resolution is something that occurs between national executives in partner countries and representatives of EU institutions. For instance, the Cotonou agreement stipulates that:

The Parties acknowledge the role of the ACP Group in political dialogue based on modalities to be determined by the ACP Group and communicated to the European Community and its Member States. The ACP Secretariat and the European Commission shall exchange all required information on the process of political dialogue carried out before, during and after consultations undertaken under Articles 96 and 97 of this Agreement.

(ACP \& EU, 2000: Annex VII, Article 3(4))

In the early years of Cotonou, dispute settlement through article 96 was frequent with 10 instances of non-execution consultations taking place between 2000 and 2005 (Saltnes, 2018: 170). When Cotonou was revised in Luxembourg in 2005, ACP partners advocated for expanding political dialogue from a bilateral setting between one ACP state and EU institutions to give the possibility to include the ACP as a whole as well as the Joint Parliamentary Assembly in the dialogue. ACP negotiators gained support for their view and the agreement was revised accordingly (Gomes, 2013). This expansion of actors is, however, limited mainly to a variety of national executives. The access of the joint parliamentary assembly in the dialogue goes some way in opening up for broader political participation, yet it remains in the hands of the national executives to decide whether stakeholders are invited into the consultation procedure.

Detractors to a broad and multi-stakeholder approach would argue that foreign policy is different from domestic politics given that the aim of foreign policy is the protection of the state (Thym, 2006 in Sjursen, 2018). One can therefore not expect the same level of democratic scrutiny by representative institutions as in domestic politics. However, from a viewpoint of justice as impartiality, such critique would be rejected. Rather, to secure the individual's freedom, individuals must be granted access to some form of democratic participation, also at the international level. Whereas democratic participation, in the form we see in democratic nations states, would not be possible, 
justice as impartiality emphasises that avenues for securing access to individuals' participation is essential for global political justice. It is on this element of individuals access to participation that the EU's conditionality policy is limited: The EU's ambition to conduct a rights-based policy has not reflected a call for a democratic participation in EU-ACP dialogue and consultations on human rights violations. These processes have largely remained in the hands of EU and national executives. There are examples where a participatory approach has been tried. For instance, in article 96 consultations between the EU and Mauritania following a coup in 2005, for instance, civil society actors were invited and took active part in the dispute settlement (Garcia Perez, 2007). However, this example is not representative of the EU's approach.

A policy that emphasises universal human rights but nevertheless fails to extend the discussion of how to approach human rights violations to democratically representative institutions or civil society actors in the affected country is vulnerable to charges of paternalistic intervention. Justifying measures to protect individuals from harm, without these individuals being represented through democratic institutions or even being informed of the issues that are being discussed, can easily lead to charges of paternalism or neo-imperial intervention.

The second ambiguity is closely connected to the first. Extending the problematisation of political dialogue as an executive authority to authority process, it is possible to question the element of delegation of authority to initiate or request an initiation of dispute settlement. In fact, also the element of access to initiate dispute settlement remains in the hands of the parties to the agreement. Cotonou Article 96 (2a) states:

If, despite the political dialogue on the essential elements as provided for under Article 8 and paragraph 1a of this Article, a Party considers that the other Party fails to fulfil an obligation stemming from respect for human rights, democratic principles and the rule of law referred to in Article 9(2), it shall, except in cases of special urgency, supply the other Party and the Council of Ministers with the relevant information required for a thorough examination of the situation with a view to seeking a solution acceptable to the Parties. To this end, it shall invite the other Party to hold consultations that focus on the measures taken or to be taken by the Party concerned to remedy the situation in accordance with Annex VII.

(ACP \& EU, 2000)

Further, Article 96(1a) states:

Within the meaning of this Article, the term 'Party' refers to the Community and the Member States of the European Union, of the one part, and each ACP State, of the other part.

(ACP \& EU, 2000)

Accordingly, only the parties to the agreement have the delegate authority to initiate article 96, thereby also to define what in their view constitutes a failure to fulfil obligations. In practice, the requesting party has always been the EU, and the decision 
to request an initiation of Article 96 is made by the Council. The European Parliament has on several occasions requested the Council to initiate article 96 through EP resolutions, however, without success. For instance, on 13 March 2014, the EP adopted a resolution requesting the Council to launch 'consultations to suspend Uganda and Nigeria from the Cotonou Agreement in view of recent legislation further criminalising homosexuality' (European Parliament, 2014). Consultations were never initiated, and the EU continued its aid to Uganda and Nigeria (Saltnes, 2020). In practice then, the decision to initiate Article 96 is restricted to representatives from the executive authorities (diplomats) of the EU's member states. The EU's approach is low on delegation of authority. From a perspective of justice as impartiality, the EU's approach does not go far enough in enabling individuals to influence the decisions that affect them.

To support rights-holders to claim their rights, one could envisage that also civil society or individuals could be empowered to request an initiation of the human rights clause. ${ }^{8}$ Equivalent procedures do exist on economic matters. For instance, under the Trade Barriers Regulation, companies and industry associations are enabled to issue a complaint to the Commission 'alleging violations of trade obligations' (Bartels, 2017: 32 ). Hence the lack of a complaint mechanism on human rights violations does not only stand in contrast to the EU's commitment to democratic principles and participation, it also stands in contrast to equivalent mechanisms in areas outside of trade and development. The EU, nevertheless, takes the view that participation and consultations with stakeholders in member states are taken care of through making the agreement legally binding: 'While ratifying a legally-binding agreement can be more cumbersome than agreeing on a political declaration, the ratification process is more democratic, increases involvement from national stakeholders and improves accountability' (European Commission \& High Representative, 2016a: 67).

In sum, the basis for individuals' autonomy and accountability for the realisation of human rights to a broad set of national and international actors is not reflected in the EU's approach. Furthermore, when placing the responsibility to initiate dispute settlement and conduct consultations on human rights violations on government to government political dialogue, there is a prioritisation of support to duty-bearers (states) to fulfil their human rights obligations over support to empowerment of rightsholders to realise their human rights.

\section{Conclusion}

The European Union commits to conduct a rights-based development policy. In light of recent literature, which has hypothesised a change in the Union's approach to development in a direction of a more interest-driven and security oriented approach, this working paper set out to investigate whether there has been a similar weakening in

${ }^{8}$ See Bartels (2017: 32-33) for a discussion of alternative ways this could be done. 
the EU's commitment to a rights-based approach in the their approach to postCotonou. I find that the post-Cotonou mandate does not confirm the hypothesis that the EU's rights-based approach is abandoned in favour of a more interest-driven approach. In fact, contrary to the hypothesis of a change, the concern for upholding human rights as essential elements of the agreement as well as the concern for not downgrading human rights commitments in self-standing EPA agreements determined the EU's negotiating directives and explains why the EU opted for a so called umbrella agreement. Accordingly, the distributional changes pointed to in the literature, which indicate a more interest-driven development policy, do not go hand in hand with an equivalent change in the EU's ambition to operate as a rights-based, global actor.

Notwithstanding the importance given by the EU on locking in human rights commitments in post-Cotonou, this paper has, however, argued that there are limits and ambiguities connected to the EU's rights-based approach. I have argued that the human rights clause that the EU operates with in the Cotonou agreement and which also is proposed for the post-Cotonou agreement follows an executive driven logic. In other words, human rights violations are discussed and resolved between national executives in partner countries and delegated officials from the EU's supranational institutions. This finding affects conditions for global political justice.

Proponents of equal sovereignty between states would perhaps not question the fairness of an executive-driven solution to human rights dispute settlement based on the assumption that the aim of foreign policy is the protection of the state and that one therefore cannot expect the same level of democratic scrutiny by representative institutions as in domestic politics. However, following from this assumption the ambition to conduct a rights-based development policy could be questioned altogether. Furthermore, proponents of cosmopolitan variants of global justice disagree with the assumption that foreign policy is best reserved for the executive branches of states.

Drawing on a concept of justice as impartiality, I have questioned the extent to which the EU's human rights clauses enhances individuals' autonomy and freedom from domination. The way in which the EU and ACP have institutionalised its human rights dialogue prioritises national executives and diplomats. Contrary to the aim of supporting rights-holders to realise their rights, individuals are not able to influence the decision to initiate dispute settlement nor participate in the settlement as such in the current design of the human rights clause (except for when national executives deem it relevant to invite them). Hence, national executives' authority to monitor and define what constitutes a violation of the Cotonou-acquis comes at the cost individuals and civil society's right to democratic participation and autonomy.

The executive driven mode of consultation identified is also relevant to consider in light of the critiques the EU has faced since its decision to include human rights conditionality in all external trade and development agreements. From its partners in the ACP states, the EU has been criticised for not sufficiently respecting the principles of equality and ownership. The right to self-determination is highly valued in ACP 
countries, many of which are young democracies and that has gone through independence struggles from European colonial masters. In particular, ACP countries have been concerned with making sure that 'external interference would not be used to undermine popular expressions of democracy that may not be favoured by European powers' (Gomes, 2013: 716). An executive driven mode of consultation at the global level might be particularly vulnerable to criticisms of not respecting equality and the spirit of partnership and to charges of paternalism. This is because executives' decisions are made behind closed doors and not open to deliberation and scrutiny by elected representatives.

The global justice approach applied in this paper complements the insights gained by interest-based and postcolonial literatures on what stands in the way of a fair development policy. Drawing on a concept of justice as impartiality, I have argued that while the EU's development policy is shaped by the ambition to strengthen a universal and law-based approach to sustainable development, this ambition also comes with duties that the EU has struggled to uphold. The EU's political conditionality policy in practice prioritises support to duty-bearers (states) to uphold their obligations over the empowerment of rights-holders (individuals) to claim their rights. Accordingly, one can ask whether the EU's approach contributes to reinforce executive dominance more than advance a policy that enhances individuals' right to participation and autonomy. 


\section{Interviews}

Interview 1 - Commission representative, DG Devco, 11.08.16, Telephone

Interview 2 - Commission representative, DG Devco, 31.08.16, Brussels

Interview 3 - EP representative, Deve and ACP committee, 01.09.16, Brussels

Interview 4 - EP senior representative, DEVE and ACP committee, 01.09.16, Brussels

Interview 5 - EP representative, Deve and ACP committee, 30.05.18, Brussels

Interview 6 - EP representative, Deve and ACP committee, 30.05.18, Brussels

Interview 7 - Commission senior representative, DG Devco, 13.01.20, Telephone

Interview 8 - EEAS senior representative, 13.01.20, Telephone

\section{References}

Abbott, K.W., Keohane, R.O., Moravcsik, A., Slaughter, A. \& Snidal, D. (2000) 'The Concept of Legalization', International Organization, 54(3): 401-419.

ACP (2018) ACP Negotiating Mandate for a Post-Cotonou Partnership Agreement with the European Union. Available at: http://www.acp.int/sites/acpsec.waw.be/ files/acpdoc/public-documents/ACPooo1118 \%20ACP Negotiating Mandate EN.pdf [accessed 18 February 2020].

ACP \& EU (2000) Partnership Agreement between the Members of the African, Caribbean and Pacific Group of States of the One Part, and the European Community and Its Member States, of the Other Part, Signed in Cotonou on 23 June 2000, Official Journal of the European Union L 317/3. Available at: https://eurlex.europa.eu/legal-content/EN/TXT/?uri=celex:22000A1215(01) [accessed 27 March 2020].

Aggestam, L. (2008) 'Introduction: Ethical Power Europe?', International Affairs, 84(1): 1-11.

Bartels, L. (2015) 'The EU's Human Rights Obligations in Relations to Policies with Extraterritorial Effects', The European Journal of International Law, 25(4): 10711091.

Bartels, L. (2017) Human Rights Provisions in Economic Partnership Agreements in Light of the Expiry of the Cotonou Agreement in 202O, Brussels: European Union.

Beck, U. (2006) Cosmopolitan Vision, Oxford: Polity. 
Beke, L., D'Hollander, D., Hachez, N. \& Pérez de las Heras, B. (2014) The Integration of Human Rights in EU Development and Trade Policies, Leuven: Leuven Centre for Global Governance Studies. Available at: http://www.fp7-frame.eu/wpcontent/uploads/2016/08/07-Deliverable-9.1.pdf [accessed 27 March 2020].

Bergmann, J., Delputte, S., Keijzer, N. \& Verschaeve, J. (2019) 'The Evolution of the EU's Development Policy: Turning Full Circle', European Foreign Affairs Review, 24(4): 533-554.

Bilal, S. \& Ramdoo, I. (2016) Sustainability and Human Rights in EPAs: A Comparative Analysis between the Caribbean and African EPAs, Maastricht: European Centre for Development Policy Management.

Broberg, M. (2013) 'From Colonial Power to Human Rights Promoter: On the Legal Regulation of the European Union's Relations with the Developing Countries', Cambridge Review of International Affairs, 26(4): 675-687.

Carbone, M. (2011) 'Development Policy: The EU as a Multilateral and Bilateral Donor', in J.U. Wunderlich \& D. Bailey (eds) The European Union and Global Governance: A Handbook, London: Routledge, pp. 157-165.

Carbone, M. (2013a) 'International Development and the European Union's External Policies: Changing Contexts, Problematic Nexuses, Contested Partnerships', Cambridge Review of International Affairs, 26(3): 483-496.

Carbone, M. (2013b) 'An Uneasy Nexus: Development, Security and the EU's African Peace Facility', European Foreign Affairs Review, 18(4): 103-124.

Carbone, M. (2019) 'Purposefully Triggering Unintended Consequences: The European Commission and the Uncertain Future of the EU-ACP Partnership', International Spectator, 54(1): 45-59.

Castillejo, C. (2017) The European Union Trust Fund for Africa: What Implications for Future EU Devleopment Policy?, Bonn: German Development Institute.

Commission of the European Communities (1972) Memorandum on a Community Policy on Development Cooperation: Synoptic and Programme for Initial Actions. Available at: https://op.europa.eu/en/publication-detail/-/publication/bco461df94fd-4ebg-b7f6-ddef1odo5aef [accessed 27 Mars 2020].

CONCORD (2018a) Aid Watch 2018: Aid and Migration. Available at: https://library.concordeurope.org/record/2063/files/DEEEP-PAPER-2019o08.pdf [accessed 27 March 2020].

CONCORD (2018b) Aid Watch 2018: Security Aid. Available at: https://library.concordeurope.org/record/2061/files/DEEEP-PAPER-2019007.pdf [accessed 27 March 2020].

Cornwall, A. \& Nyamu-Musembi, C. (2004) 'Putting the "Rights-Based Approach" to Development into Perspective', Third World Quarterly, 25(8): 1415-1437.

Council of Ministers (2012) EU Strategic Framework and Action Plan on Human Rights and Democracy, 11855/12, 25 June. Available at: https://www.consilium.europa.eu/uedocs/cms data/docs/pressdata/EN/foraff/1 31181.pdf [accessed 18 February 2020]. 
Council of Ministers (2014) Council Conclusions on a Rights-Based Approach to Development Cooperation, Encompassing All Human Rights. Brussels: Council of the European Union. Available at: https://www.consilium.europa.eu/uedocs/ cms data/docs/pressdata/en/foraff/142682.pdf [accessed 18 February 2020].

Council of Ministers (2018) Negotiating Directives for a Partnership Agreement between the European Union and Its Member States on the One Part, and with Countries of the African, Caribbean and Pacific Group of States, of the Other Part, 8094/18, 21 June. Available at: https://data.consilium.europa.eu/doc/ document/ST-8094-2018-ADD-1/en/pdf [accessed 18 February 2020].

Crawford, G. (2001) Foreign Aid and Political Reform: A Comparative Analysis of Democracy Assistance and Political Conditionality, Basingstoke: Palgrave Macmillan.

Crawford, G., \& Kacarska, S. (2019) 'Aid Sanctions and Political Conditionality: Continuity and Change', Journal of International Relations and Development, 22(1): 184-214.

D'Hollander, D., Marx, A. \& Wouters, J. (2014) Integrating Human Rights in EU Development Cooperation Policy: Achievements and Challenges, Leuven: Leuven Centre for Global Governance Studies.

EEAS (2016) A Global Strategy for the European Union's Foreign and Security Policy. Shared Vision, Common Action: A Stronger Europe. Available at: https://eeas.europa.eu/topics/eu-global-strategy/17304/global-strategyeuropean-unions-foreign-and-security-policy en [accessed 27 March 2020].

EPC Bulletin (1991) Resolution of the Council and of the Member States Meeting in the Council on Human Rights, Democracy and Development, Volume 24, No 11, Brussels: Commission of the European Communities. Available at: https://op.europa.eu/en/publication-detail/-/publication/152e74ao-c1dd-4fo58125-a675bbod251d/language-en [accessed 18 February 2020].

Eriksen, E.O. (2009) 'The EU: A Cosmopolitan Vanguard?', Global Jurist, 9(1): 1-23.

Eriksen, E.O. (2016) 'Three Conceptions of Global Political Justice', GLOBUS Research Papers 1/2016, Oslo: ARENA.

European Commission (2014) Commission Staff Working Document. Tool-Box: A Rights-Based Approach, Encompassing All Human Rights for EU Development Cooperation, SWD(2014) 152 final, 30 April. Available at: https://ec.europa.eu/ transparency/regdoc/rep/10102/2014/EN/10102-2014-152-EN-F1-1.Pdf [accessed 18 February 2020].

European Commission (2017) Recommendation for a Council Decision Authorising the Opening of Negotiations on a Partnership Agreement between the European Union and Countries of the African, Caribbean and Pacific Group of States, COM(2017) 763 final. Available at: https://eur-lex.europa.eu/legal-content/en/TXT/?uri=CELEX\% 3A52017PC0763 [accessed 27 March 2020].

European Commission (2020) Overview of Economic Partnership Agreements: Updated March 2020. Available at: https://trade.ec.europa.eu/doclib/docs/2009/ september/tradoc 144912.pdf [accessed 27 March 2020]. 
European Commission \& High Representative (2011) Joint Communication to the European Parliament and the Council: Human Rights and Democracy at the Heart of EU External Action: Towards a More Effective Approach, COM(2011) 886 final, 12 December. Available at: https://ec.europa.eu/transparency/regdoc/rep/1/2011/ EN/1-2011-886-EN-F1-1.Pdf [accessed 18 February 2020].

European Commission \& High Representative (2016a) Impact Assessment Accompanying the Document Joint Communication to the European Parliament and the Council. A Renewed Partnership with the Countries of Africa, the Caribbean and the Pacific, SWD(2016) 381 final, 22 November. Available at: https://eurlex.europa.eu/legal-content/EN/TXT/?uri=SWD:2016:380:FIN [accessed 27 March 2020].

European Commission \& High Representative (2016b) Joint Communication to the European Parliament and the Council. A Renewed Partnership with the Countries of Africa, the Caribbean and the Pacific, SWE(2016) 380 final, 22 November. Available at: https://eur-lex.europa.eu/legal-content/EN/TXT/?uri=JOIN:2016: 0052:FIN [accessed 26 March 2020].

European Commission and EEAS (2016) 'Towards a New Partnership Between the European Union and the African, Caribbean and Pacific Countries After 2020 Summary Report of the Public Consultation'. Available at: https://ec.europa.eu/international-partnerships/system/files/summary-reportpublic-consultation-eu-acp en.pdf [accessed 19 April 2020].

European Parliament (2014) Consultations to Suspend Uganda and Nigeria from the Cotonou Agreement in View of Recent Legislation Further Criminalising Homosexuality, 2014/2634(RSP). Available at: https://eur-lex.europa.eu/legalcontent/EN/TXT/?uri=CELEX\%3A52014IP0254 [accessed 27 March 2020].

European Parliament (2016) 'Report on the Future of ACP-EU Relations Beyond 2020', (2016/2053(INI)), Brussels: European Parliament. Available at: https://www.europarl.europa.eu/doceo/document/A-8-2016-0263 EN.html [accessed 27 March 2020].

European Union (1992) The Treaty of Maastricht. Brussels: Official Journal of the European Union. Available at: https://europa.eu/european-union/sites/europaeu/ files/docs/body/treaty on european_union_en.pdf [accessed 27 March 2020].

European Union (2007) The Treaty of Lisbon Amending the Treaty on European Union and the Treaty Establishing the European Community. Brussels: Official Journal of the European Union. Available at: https://eur-lex.europa.eu/legalcontent/EN/TXT/?uri=celex:12007L/TXT [accessed 18 February 2020].

Forst, R. (2015) 'Domination, Global Harms, and the Priority of Injustice: Expanding Transnational Republicanism', in B. Buckinx, J. Trejo-Mathys \& T. Waligore (eds) Domination and Global Political Justice: Conceptual, Historical and Institutional Perspectives, New York, NY: Routledge.

Forst, R. (2018) 'Human Rights in Context: A Comment on Sangiovanni', in A. Etinson (ed.) Human Rights: Moral or Political?, Oxford: Oxford University Press.

France 24 (2019) Interview with Paul Kgame and Neven Mimica, France 24, 24 June. Available at: https://www.youtube.com/watch?v=LXY1ttn-4SU\&t=1229s [accessed 30 March 2020]. 
Furness, M. \& Gänzle, S. (2017) 'The Security-Development Nexus in European Union Foreign Relations after Lisbon: Policy Coherence at Last?', Development Policy Review, 35(4): 475-492.

Garcia Perez, M. (2007) 'Human Rights in EU Development Cooperation: A Practitioner's Perspective', in M. Salomon, A. Tostensen \& W. Vandenhole (eds) Casting the Net Wider: Human Rights, Development and New Duty-Bearers, Antwerp: Inersentia.

Gerring, J. (2007) Case Study Research: Principles and Practices, Cambridge: Cambridge University Press.

Gomes, P.I. (2013) 'Reshaping an Asymmetrical Partnership: ACP-EU Relations from an ACP Perspective', Journal of International Development, 25(5): 714-726.

Hadfield, A. (2007) 'Janus Advances? An Analysis of EC Development Policy and the 2005 Amended Cotonou Partnership Agreement', European Foreign Affairs Review, 12(1): 39-66.

Hadfield, A. \& Lightfoot, S. (2020) 'The Future of EU Development Policy Post-2020', GLOBUS Research Papers 1/2020, Oslo: ARENA.

Holland, M. \& Doidge, M. (2012) Development Policy of the European Union, Basingstoke: Palgrave Macmillan.

Keijzer, N. \& Bartels, L. (2017) Assessing the Legal and Political Implications of the Post-Cotonou Negotiations for Economic Partnership Agreements, Bonn: German Development Institute.

Keohane, R.O., Moravcsik, A. \& Slaughter, A.M. (2000) 'Legalized Dispute Resolution: Interstate and Transnational', International Organization, 54(3): 457-488.

Keukeleire, S. \& Raube, K. (2013) 'The Security-Development Nexus and Securitization in the EU's Policies towards Developing Countries', Cambridge Review of International Affairs, 26(3): 556-572.

Langan, M. (2018a) Neo-Colonialism and the Poverty of 'Development' in Africa, Cham: Palgrave Macmillan.

Langan, M. (2018b) 'Security, Development and Neo-Colonialism', in M. Langan (ed.) Neo-Colonialism and the Poverty of 'Development' in Africa, Houndmills: Palgrave Macmillan, pp. 149-175.

Lavenex, S. \& Kunz, R. (2008) 'The Migration-Development Nexus in EU External Relations', Journal of European Integration, 30(3): 439-457.

Manners, I. (2002) 'Normative Power Europe: A Contradiction in Terms?', Journal of Common Market Studies, 40(2): 235-258.

Mikalsen, K. (2017) 'Equal Sovereignty: On the Conditions of Global Political Justice', GLOBUS Research Papers 3/2017, Oslo: ARENA.

Nussbaum, M. (1999) 'In Defence of Universal Values', Occational Paper Series, 16:OP:1. Available at: https://humanities-web.s3.us-east-2.amazonaws.com/ philosophy/prod/2018-10/In\%20Defense\%20of\%20Universal\%20Values.pdf [accessed 23 March 2020].

Olsen, G.R. (2002) 'The European Union: An Ad Hoc Policy with a Low Priority', in P.J. Schraeder (ed.) Exporting Democracy: Rethoric Vs. Reality, Boulder, CO: Lynne Rienner Publishers. 
Orbie, J. \& Delputte, S. (2019) Let's Abolish the EU Commissioner for Development, EU Observer, 9 May.

Orbie, J., Bossuyt, P., Debusscher, K., Del Biondo, K., Delputte, S., Reynaert, V. \& Verschaeve, J. (2017) 'The Normative Distinctiveness of the European Union in International Development: Stepping out of the Shadow of the World Bank?', Development Policy Review, 35(4): 493-511.

Pallotti, A. (2018) 'The European Union and Africa: Depoliticised Development and the Elusive Quest for Democracy and Security', GLOBUS Research papers 13/2018, Oslo: ARENA.

Parkes, R. (2017) Nobody Move! Myths of the EU Migration Crisis, Paris: EU Institute for Security Studies. Available at: https://www.iss.europa.eu/sites/default/ files/EUISSFiles/CP 143 Migration o.pdf [accessed 9 April 2020].

Price, S. (2019) 'The Impact of Brexit on EU Development Policy', Politics and Governance, 7(3): 78-82.

Rawls, J. (1971) A Theory of Justice, Oxford: Oxford University Press.

Rosecrance, R. (1998) 'The European Union: A New Type of International Actor', in J. Zielonka (ed.) Paradoxes of European Foreign Policy, The Hague: Kluwer Law International, pp. 15-23.

Rutazibwa, O.U. (2010) 'The Problematics of the EU's Ethical (Self)Image in Africa: The EU as an "Ethical Intervener" and the 2007 Joint Africa-EU Strategy', Journal of Contemporary European Studies, 18(2): 209-228.

Saltnes, J.D. (2018) 'The European Union's Human Rights Policy: Is the EU's Use of the Human Rights Clause Inconsistent?', Global Affairs, 4(2-3): 277-289.

Saltnes, J.D. (2020) 'To Sanction or Not to Sanction? Normative Dilemmas in the Promotion of LGBTI Human Rights', GLOBUS Research Papers 2/2020, Oslo: ARENA.

Sjursen, H. (2017) 'Global Justice and Foreign Policy: The Case of the European Union', GLOBUS Research Papers 2/2017, Oslo: ARENA.

Sjursen, H. (2018) 'The Legitimacy of European Union Foreign Policy', Global Affairs, 4(2-3): 253-264.

Smith, K.E. (1998) 'The Use of Political Conditionality in the EU's Relations with Third Countries: How Effective?', European Foreign Affairs Review, 3(2): 253-274.

Smith, K.E. (2014) European Union Foreign Policy in a Changing World, Cambridge: Polity.

Staeger, U. (2016) 'Africa-EU Relations and Normative Power Europe: A Decolonial Pan-African Critique', Journal of Common Market Studies, 54(4): 981-998.

Taylor, I. (2016) 'Bait and Switch: The European Union's Incoherency Towards Africa', Insight on Africa, 8(2): 96-111.

Uvin, P. (2004) Human Rights and Development, Bloomfield: Kumarian Press.

Uvin, P. (2007) 'From the Right to Development to the Rights-Based Approach: How "Human Rights" Entered Development', Development in Practice, 17(4): 597-606. 
Van den Putte, L., Orbie, J., Bossuyt, P. \& De Ville, F. (2013) 'Social Norms in EU Bilateral Trade Agreements: A Comparative Overview, in T. Takacs, A. Ott \& A. Dimopoulos (eds) Linking Trade and Non-Commercial Interests: The EU as a Global Role Model, Den Haag: TMC Asser Institute, pp. 35-48.

Whitman, R. (1998) From Civilian Power to Superpower? The International Identity of the European Union, Basingstoke: Palgrave Macmillan.

Youngs, R. (2008) 'Fusing Security and Development: Just Another Euro-Platitude?', Journal of European Integration, 30(3): 419-437.

Youngs, R. (2010) The European Union and Democracy Promotion: A Critical Global Assessment, Baltimore, MD: John Hopkins University Press. 


\section{Annex I: Human rights clauses}

\section{The Human rights clause as stipulated in the Cotonou Agreement}

\section{Article 9}

Essential Elements and Fundamental Element

1. Cooperation shall be directed towards sustainable development centred on the human person, who is the main protagonist and beneficiary of development; this entails respect for and promotion of all human rights.

Respect for all human rights and fundamental freedoms, including respect for fundamental social rights, democracy based on the rule of law and transparent and accountable governance are an integral part of sustainable development.

2. The Parties refer to their international obligations and commitments concerning respect for human rights. They reiterate their deep attachment to human dignity and human rights, which are legitimate aspirations of individuals and peoples. Human rights are universal, indivisible and inter-related. The Parties undertake to promote and protect all fundamental freedoms and human rights, be they civil and political, or economic, social and cultural. In this context, the Parties reaffirm the equality of men and women.

The Parties reaffirm that democratisation, development and the protection of fundamental freedoms and human rights are interrelated and mutually reinforcing. Democratic principles are universally recognised principles underpinning the organisation of the State to ensure the legitimacy of its authority, the legality of its actions reflected in its constitutional, legislative and regulatory system, and the existence of participatory mechanisms. On the basis of universally recognised principles, each country develops its democratic culture.

The structure of government and the prerogatives of the different powers shall be founded on rule of law, which shall entail in particular effective and accessible means of legal redress, an independent legal system guaranteeing equality before the law and an executive that is fully subject to the law.

Respect for human rights, democratic principles and the rule of law, which underpin the ACP-EU Partnership, shall underpin the domestic and international policies of the Parties and constitute the essential elements of this Agreement.

3. In the context of a political and institutional environment that upholds human rights, democratic principles and the rule of law, good governance is the transparent and 
accountable management of human, natural, economic and financial resources for the purposes of equitable and sustainable development. It entails clear decision-making procedures at the level of public authorities, transparent and accountable institutions, the primacy of law in the management and distribution of resources and capacity building for elaborating and implementing measures aiming in particular at preventing and combating corruption.

Good governance, which underpins the ACP-EU Partnership, shall underpin the domestic and international policies of the Parties and constitute a fundamental element of this Agreement. The Parties agree that only serious cases of corruption, including acts of bribery leading to such corruption, as defined in Article 97 constitute a violation of that element.

4. The Partnership shall actively support the promotion of human rights, processes of democratisation, consolidation of the rule of law, and good governance.

These areas will be an important subject for the political dialogue. In the context of this dialogue, the Parties shall attach particular importance to the changes underway and to the continuity of the progress achieved. This regular assessment shall take into account each country's economic, social, cultural and historical context.

These areas will also be a focus of support for development strategies. The Community shall provide support for political, institutional and legal reforms and for building the capacity of public and private actors and civil society in the framework of strategies agreed jointly between the State concerned and the Community.

\section{Article 96}

1. Within the meaning of this Article, the term 'Party' refers to the Community and the Member States of the European Union, of the one part, and each ACP State, of the other part.

1.(a) Both Parties agree to exhaust all possible options for dialogue under Article 8, except in cases of special urgency, prior to commencement of the consultations referred to in paragraph 2(a) of this Article.

2.(a) If, despite the political dialogue on the essential elements as provided for under Article 8 and paragraph 1a of this Article, a Party considers that the other Party fails to fulfil an obligation stemming from respect for human rights, democratic principles and the rule of law referred to in Article 9(2), it shall, except in cases of special urgency, supply the other Party and the Council of Ministers with the relevant information required for a thorough examination of the situation with a view to seeking a solution acceptable to the Parties. To this end, it shall invite the other Party to hold consultations that focus on the measures taken or to be taken by the Party concerned to remedy the situation in accordance with Annex VII. 
The consultations shall be conducted at the level and in the form considered most appropriate for finding a solution.

The consultations shall begin no later than 30 days after the invitation and shall continue for a period established by mutual agreement, depending on the nature and gravity of the violation. In no case shall the dialogue under the consultations procedure last longer than 120 days.

If the consultations do not lead to a solution acceptable to both Parties, if consultation is refused or in cases of special urgency, appropriate measures may be taken. These measures shall be revoked as soon as the reasons for taking them no longer prevail.

(b) The term 'cases of special urgency' shall refer to exceptional cases of particularly serious and flagrant violation of one of the essential elements referred to in paragraph 2 of Article 9, that require an immediate reaction.

The Party resorting to the special urgency procedure shall inform the other Party and the Council of Ministers separately of the fact unless it does not have time to do so.

(c) The 'appropriate measures' referred to in this Article are measures taken in accordance with international law, and proportional to the violation. In the selection of these measures, priority must be given to those which least disrupt the application of this agreement.

It is understood that suspension would be a measure of last resort.

If measures are taken in cases of special urgency, they shall be immediately notified to the other Party and the Council of Ministers. At the request of the Party concerned, consultations may then be called in order to examine the situation thoroughly and, if possible, find solutions. These consultations shall be conducted according to the arrangements set out in the second and third subparagraphs of paragraph (a).

Source: (ACP \& EU, 2000)

\section{Proposed final provisions in the EU's Post-Cotonou Mandate}

\section{Fulfilment of obligations}

The Agreement will foresee the possibility for a Party to take appropriate measures in case the other Party has failed to fulfil any of its obligations in relation to the essential and fundamental elements. 
In such cases, appropriate measures should be taken following prior consultations between the Parties. Consultations should be held at the level and in the form considered most appropriate for reaching a solution and within a defined timeframe.

In order to prevent situations arising in which one Party considers that the other Party has failed to fulfil its commitments in relation to the essential and fundamental elements of the Agreement, structured and systematic consultations will be held on concerns raised.

Whilst the bilateral character of the consultations will be preserved, the Parties will commit to consult and coordinate with all relevant regional and international actors in the preparations of each consultation session.

The Agreement will also ensure the possibility for a Party to take appropriate measures should the consultations be refused or fail to deliver mutually acceptable results, as well as in cases of special urgency without the need for prior consultations. 'Appropriate measures' and 'cases of special urgency' should be defined as in the CPA under Article 962 (b) and 2(c).

\section{Dispute settlement}

The Agreement will include a provision on an appropriate and effective dispute settlement mechanism in case of divergence in the application, interpretation and implementation of the Agreement.

Source: (Council of Ministers, 2018, pp. 85-86) 
GLOBUS Research Papers

10/2020

Johanne Døhlie Saltnes

A Break from the Past or Business as Usual?

EU-ACP Relations at a Crossroad

9/2020

Heidi Riley

Shifting Conceptions of Gender Justice in EU Policy on Women Peace and Security

$8 / 2020$

Richard Maher

EU Foreign Policy and Humanitarian Intervention

Justice in a Disordered World

$7 / 2020$

Giorgio Grappi

Europe and the Contested Politics of Migration

Between Logistification and Global Justice

$6 / 2020$

Katharina L. Meissner

Cohesion, (non-)Domination, and

Regional Organisations in the EUSADC EPA Negotiations

$5 / 2020$

Nikola Tomić

Between Border Dispute and Ethnic

Conflict

The EU as a Just Mediator in the

Serbia-Kosovo Stalemate

$4 / 2020$

Ben Tonra

Resilience and the EU's Global Strategy

The Potential Promise of Justice
$3 / 2020$

Solveig Aamodt and Elin Lerum Boasson

From Impartial Solutions to Mutual

Recognition

Explaining Why the EU Changed Its

Procedural Climate Justice

Preferences

$2 / 2020$

Johanne Døhlie Saltnes

To Sanction or Not to Sanction?

Normative Dilemmas in the Promotion of LGBTI Human Rights

$1 / 2020$

Amelia Hadfield and Simon Lightfoot The Future of EU Development Policy Post-2020

$6 / 2019$

Antonio de Aguira Patriota Is the World Ready for Cooperative Multipolarity?

$5 / 2019$

Ivor Sarakinsky

Recognition and Obligation

EU and South Africa Renewable

Energy Development Cooperation

$4 / 2019$

Samuel Brazys, Arya Pillai and Johanne

Døhlie Saltnes

EU Aid for Trade: Mitigating Global

Trade Injustices?

$3 / 2019$

Johanne Døhlie Saltnes

Global Justice and Aid Effectiveness

Reforms of the European Union's

Development Policy 
2/2019

Franziskus von Lucke

Principled Pragmatism in Climate

Policy?

The EU and Changing Practices of

Climate Justice

$1 / 2019$

Cathrine Holst

Global Gender Justice

Distributive Justice or Participatory

Parity?

$14 / 2018$

Kholiswa Malindini and Odile Mackett

Trade Liberalisation and Female

Employment in Botswana and South

Africa

$13 / 2018$

Arrigo Pallotti

The European Union and Africa

Depoliticised Development and the

Elusive Quest for Democracy and

Security

$12 / 2018$

Sonia Lucarelli

The EU and the Crisis of Liberal Order At Home and Abroad

$11 / 2018$

Graham Finlay

The European Union as a Tolerant

Actor

$10 / 2018$

Matthieu Burnay and Marta Hermez

Towards Global Justice with Chinese

Characteristics
9/2018

Katie Verlin Laatikainen and Martin

Palouš

Contested Ground

The Campaign to Enhance the Status of the European Union in the UN

General Assembly

$8 / 2018$

Hayley Walker

Mutual Recognition in Global

Negotiations

The Case of the 2015 Paris Climate

Summit

$7 / 2018$

Cathrine Holst

Promoting Global Justice when

Backlash Strikes

EU and UN Beijing +20

$6 / 2018$

Espen D.H. Olsen

Out but Still In

Norway's Approach to Migration and

Asylum as a non-EU State

$5 / 2018$

Samuel Brazys and Krishna C.

Vadlamannati

Aid Curse with Chinese

Characteristics?

Chinese Development Flows and

Economic Reform

$4 / 2018$

Michela Ceccorulli

On Protection and Justice

The Proposals for Reform of the

Common European Asylum System

$3 / 2018$

Ben Tonra

The (In)Justices of Peacekeeping

EUFOR Tchad/RCA 
2/2018

Nikola Tomić and Ben Tonra

The Pursuit of Justice through EU

Security Strategies

Sisyphus Redux?

$1 / 2018$

Alexa Zellentin

Different Angles on Climate Justice Insights from Non-domination and Mutual Recognition

$6 / 2017$

Mai'a K. Davis Cross

Europe's Foreign Policy and the Nature of Secrecy

$5 / 2017$

Bettina Ahrens

The Solidarisation of International

Society

The EU in the Global Climate Change Regime
$4 / 2017$

Mai'a K. Davis Cross

EU Institutions and the Drive for Peace The Power of Ideas

$3 / 2017$

Kjartan Koch Mikalsen

Equal Sovereignty

On the Conditions of Global Political Justice

2/2017

Helene Sjursen

Global Justice and Foreign Policy

The Case of the European Union

$1 / 2017$

Franziskus von Lucke

O Justice, Where Art Thou?

Developing a New Take on Climate

Justice

$1 / 2016$

Erik O. Eriksen

Three Conceptions of Global Political Justice 


\section{GLOBUS Research Papers}

The GLOBUS Research Papers are pre-print manuscripts on the EU's contribution to global justice as well as the wider question of Global Political Justice. The series is multidisciplinary, with a particular emphasis on the fields of international relations, political science, political theory, sociology and law.

\section{Reconsidering European Contributions to Global Justice - GLOBUS}

GLOBUS is a research project that critically examines the European Union's contribution to global justice. Challenges to global justice are multifaceted and what is just is contested. Combining normative and empirical research GLOBUS explores underlying political and structural obstacles to justice. Analyses of the EU's positions and policies are combined with in-depth studies of non-European perspectives on the practices of the EU. Particular attention is paid to the fields of migration, trade and development, cooperation and conflict, as well as climate change. GLOBUS' team of researchers covers the disciplines of politics, international relations, law, economics, sociology and political theory. The project is coordinated by ARENA Centre for European Studies at the University of Oslo and has partners in Brazil, China, Germany, India, Ireland, Italy and South Africa. It is funded by the Horizon 2020 Programme of the European Union for the period 1.6.2016 - 31.5.2020.

\section{Series Editor}

Helene Sjursen, ARENA Centre for European Studies, University of Oslo GLOBUS Coordinator

\section{Editorial Board}

Thomas Diez

Erik O. Eriksen

Sonia Lucarelli Pundy Pillay

Ben Tonra
Institute of Political Science, University of Tübingen ARENA Centre for European Studies, University of Oslo Department of Political and Social Sciences, University of Bologna Wits School of Governance, University of Witwatersrand School of Politics and International Relations, University College Dublin 